\title{
The Computer Network: the New Perspective of Construction of Business English Teaching
}

\author{
Wanfang Zhang, Min Luo \\ School of Foreign Languages \\ Wuhan Polytechnic University \\ Wuhan 430023; China \\ E-mail: zhangwanfang2006@yahoo.com.cn
}

\begin{abstract}
The drawbacks of Traditional business English teaching make the application of computer network technology a new trend in the development of business English courses. They open new ideas for reforming business English teaching. On the basis of constructing the specific modes of business English teaching under the environment of computer networks, this paper explores the problems that exist in multimedia computer-assisted business English teaching as well.
\end{abstract}

Keywords- computer network; business English teaching; construction

\section{INTRODUCTION)}

The traditional business English teaching has been unable to meet the demand for talents in contemporary society. Its drawbacks make the application of computer network technology a new trend in the development of business English courses. On the basis of building a specific model of business English teaching in computer network environment, this article will study problems in the multimedia computer-assisted business English teaching.

\section{ThE DraWbacks Of TRAditional Business ENGLISH TEACHING}

\section{A. Outdated Teaching Modes and Single Means}

The traditional business English teaching in which the cramming teaching model plays a dominant role is likely to overlook students' initiatives and their own personality. At the same time, the traditional business English teaching methods are too monotonous, which rely on teachers' teaching in a scripted style. So, this kind of teaching mode can't create a real business communication environment, which makes the teaching contents boring and hard to understand and reduces the efficiency of students' learning and greatly damages their enthusiasm for learning.

B. Delay of Textbook Renewal

In universities, business English teaching materials tend to lag behind the economic development of our society, which restricts the effective training of the professional ability and quality of students. As an ESP (English for Special Purposes) used in international business and trade, business English is closely linked with rapidly changing business activities. This feature determines the fact that business English must be ever-changing. In particular, since we enter the 21st century, the rapid development of the global economy brings a new look to business English. This development is so rapid that business English teaching materials can't be timely updated.

\section{The Shortage of Teachers}

With the rapid growth in China's international business activities and the continuously increased enrollment of university students, many universities face the shortage of talents for business English teachers, especially the good ones with rich practical experience. In other words, some business English teachers have indifferent qualifications for the job.

\section{THE NECESSITY, AdVANTAGES AND}

\section{CHARACTERISTICS OF COMPUTER NETWORK TEACHING}

\section{A. The Necessity of Computer Network Teaching}

The application of technology of computer network becomes the new trend in the development of business English courses because it establishes a virtualized business environment. Business English courses, as an applied course, require more about the practice of professional capacity, curriculum design and organizational capacities of professional teachers. For those who have no business experience \& are out of business environment, it will be difficult to assimilate abstract and complex business knowledge into original cognitive structures. And also, in that case, learners have to memorize knowledge mechanically and deal with their examinations simply. Therefore, the introduction of computer network technology is an inevitable trend in the development of business English teaching under the new situation.

\section{B. The Advantages of Computer Network Teaching}

The Advantages of Computer Network in business English Teaching are as follows: 1) Vividly demonstrating the different business scenarios. The introduction of networked teaching just creates a multi-dimensional communicative environment. By Using multimedia and network technology, teachers can present a lot of data, texts, images, audio and video information to students through screens and headphones. Their visual image and graphic features make teaching methods comprehensive and multilevel. Thus, the traditional \& single English language teaching mode, "teacher - Blackboard (recorder) - students," has been altered. 2) Providing a considerable amount of real fresh business English materials. Online resources are not only large but also can be used with others. They are showed to learners vividly in various ways, such as hypertext, hypermedia, texts, images, audio, video etc. and 
will form a variety of sensory stimulation to enable students to develop habits of reading, listening and watching more. In addition, students may also use e-mail, forums to obtain and release any information resources at any time and any place. 3) Cultivating students' interest and stimulating their learning autonomy. Network has broken the limit of traditional learning in time and space. In this case, students can have their own time and space for open learning and practice. 4) Providing a relatively relaxing learning environment. Good Network interface can be a help to achieve various forms of interaction between people and people, people and information. Equal model of network provides equal communication and collaborative relationship between teachers and students. Hyperlinks and search engines can help students quickly get required learning materials. Network platform can also demonstrate the learning outcomes. By using web technology, e-mail, online forums, online communication, teachers \& students, students \& students, students \& strangers can communicate with each other. Especially in the online English writing and online communication, anxiety and nervousness of English learners can be reduced greatly. Thus, students' selfconfidence will be improved in this relatively relaxing learning environment. 5) Providing convenient information resources. As long as learners click the mouse in the Internet, the information they need will appear instantly. By computer roaming, within minutes, you can have access to library collections anywhere even though you never leave your home. Also, you can know about any information that happened in the world in the shortest time through email and video chat. In short, rapid dissemination of information offers a golden opportunity for improving the efficiency of business English learning.

\section{The Characteristics of Computer Network Teaching}

To sum up , computer network teaching overcomes the disadvantages of traditional business and has the following three features: 1) Autonomy --- In the network environment, students can no longer be the slaves to the only source of information (teachers or teaching materials) and they are likely to design and arrange their learning following the actual situation and make themselves the subject of learning, which can further stimulate students' interest and autonomy in learning. 2) Interaction --- Multimedia has the feature of strong human-computer interaction, which is conducive to the development of students' quality education, skills training and the ability to develop creative thinking in the teaching reform. Specifically speaking, teachers can communicate with students through the network and the communication among students can also be accomplished by network operations like e-mail and BBS; Students can also continuously adjust the learning content and pace, advance and retreat freely, and build a learning framework by themselves according to the feedback information provided by the network computer. 3) Individuality --- In the new teaching mode, students are placed in the most central position and become the subject of the teaching process and teachers are the organizers and guiders of teaching.

\section{THE SPECIFIC FORMS OF Business ENGLISH \\ TEACHIng Under THE ENVIRONMENT OF COMPUTER NETWORK}

there are three main forms of computer network teaching: one is its application in multimedia classrooms; the second is its application in computer networks classrooms; the third is the multimedia network control service system. On this basis, we come to discuss the specific form of business English teaching with the aid of computer networks. We should note that since it is "complementary", it should firstly be classroom-based, and then supplemented by computer networks. That is, this teaching form is still made up of teachers' teaching in classrooms. It is different from the traditional teaching just because it uses computer network as an auxiliary tool.

A. Courseware Authoring through Computer

Teachers search for various materials and pictures associated with the text and show all kinds of information visually in the form of multimedia by using computer digital technology. We can download some listening materials from the internet and add them to the courseware; we can change the writing on the blackboard into direct video teaching and add some grammar and reading exercises. This not only expands the amount of information but also changes the duck indoctrination into computer-assisted learning in a guiding way; this can increase students' learning interest and meanwhile help students timely receive and master the key points of knowledge.

B. Online Class Platform

The contents of multimedia teaching are recorded through multimedia network services and edited by professionals and then a variety of teaching information is integrated into an excellent digital course. On the one hand, teachers can improve teaching effectiveness in the process of reviewing their own teaching videos. On the other hand, the digital classroom teaching can be observed, studied and evaluated by other teachers and evaluation departments. The main purpose of an excellent digital course is surely to serve the students. Online class platform, which is constructed by editing, integrating, classifying and uploading digital classes, provides students with the second class in which students can review and consolidate knowledge.

C. Establishing a Communication Platform by Using the Network Environment

The Internet has become a rich resource library on the basis of the comprehensive classification of various resources. Therefore, the latest learning resources can be browsed and the information can be easily downloaded and learning experiences can be shared and so on. E-mail, QQ, Msn are all popular online communications means and if these means are used in business English teaching, we can achieve the desired results easily and quickly. In addition, a wealth of web images and a lot of learning materials can promote students' interest in learning greatly. In this mode of teaching, students are consistently in the real atmosphere of business English and their communicative ability has been improved rapidly. D. Online Resources Platform 
Teachers are transforming their positions from the traditional dominance to the guidance. Students can complete the assignments the teacher arranged according to their own learning methods and learning habits. They can allocate their time freely when they click on the "pages". That is, they can make more efforts to deal with difficult learning materials and sweep away those relatively simple materials and thus greatly improve their learning efficiency. Online resource library is to provide uploaded and downloaded teaching resources to achieve a variety of resource sharing. Via teaching resources server, teaching resources libraries can be built on the basis of equipping with courseware space, network classroom space, and public resources space for teaching and researching. As teaching references, teachers can have access to these teaching resources at home or in the teaching and researching department. Also, these resources can be transferred from the computer at high speed in the classroom.

\section{Problems In Business English Teaching Under THE ENVIRONMENT OF COMPUTER NETWORK}

The application of multimedia computer network technology has brought a breakthrough change in business English teaching and has made gratifying achievements. Of course, the multimedia computer network-assisted business English teaching is not without flaws. 1) Over-reliance on computer networks will make the quality of courseware low. Some teachers simply copy the knowledge points from the books to the business English courseware and don't explain, supply and expand the important and difficult points. So students have to gulp down the knowledge. 2) There will be a lack of interaction between teachers and students if they rely much on computer networks. Business English teaching focuses on improving students' English language communication skills in different business situations. If teachers rest much on the electronic courseware without paying attention to their teaching methods and means, students' initiative and creativity will be inhibited. 3) Teachers will be lazy to improve their own professional ability if too much emphasis is put on the importance of multimedia. Some Business English teachers are too addicted to the use of multimedia information technology and unable to practically improve their own professional competence in business activities. 4) Over-reliance on computer networks will result in a wrong direction for students. The extensive use of network resources and the interception of materials from them will cause students to psychologically depend on them. Students think that they needn't take efforts to memorize the information and knowledge all of which can be easily obtained from the network.

\section{CONCLUSION}

The organic integration of multimedia technology and business English teaching is a new type of teaching method. It improves the teaching effectiveness greatly by solving some issues (e.g. single teaching means, poor learning environment etc.) that exist in traditional teaching methods. The use of modern multimedia network technology in modern business English teaching not only provides a broad, flexible and creative learning space but also promotes changes in the teaching content, teaching methods and teaching modes. As business English teachers, to improve teaching quality, we should emancipate our minds and make good use of information technology. Firstly, we must grasp the latest business English knowledge and multimedia \& network knowledge. Secondly, we should adhere to the student-centered teaching philosophy. Finally, we must give full play to teachers' roles as organizers, coordinators and facilitators. Only in this way, can the perfect combination of teachers' roles and new technology be realized gradually.

\section{REFERENCES}

[1] Qi Gu. On the Applications of Computer Network Technology into English Teaching. Journal of Hubei University of Economics (Humanities and Social Sciences), 2009 (5).

[2] Fengrong Li. On the Study of College English Teaching based on Computer Network. Journal of Changchun University of Technology (Higher Education Study Edition), 2010 (2).

[3] Linghao $\mathrm{Li}$. On the Applications of the Computer Network Technology into Business English Teaching. Journal of Tianjin Manager College, 2007 (4).

[4] Lin Lin. On the Applications of Computer Networks into Business English Listening Teaching. China Electric Power Education, 2010 (24).

[5] Xiuzhen Xie. On the Applications of Multimedia Computer Network Technology into Business English Teaching. Science \& Technology Information, 2010 (1).

[6] Xueman Zhao. On the Integration of Computer and Internet into Business English Teaching Program. Computer-assisted Foreign Language Education, 2009 (4). 